\title{
Two new species of Bryconamericus Eigenmann (Characiformes: Characidae) from southern Brazil
}

\author{
José Francisco Pezzi da Silva
}

Two new species of Bryconamericus are described from southern Brazil: B. patriciae, from the headwaters of rio Pelotas (rio Uruguay drainage) and rio das Antas (laguna dos Patos drainage) and B. ecai from lower rio Taquari drainage. Bryconamericus patriciae differs from other Bryconamericus species from southern South America, by the following combination of characters: body depth (25.5-30.3\% SL); head length (25.2-27.6\% SL); pelvic-fin length (11.0-14.4\% SL); branched anal-fin rays 14-18; teeth of outer row of premaxilla regularly implanted; teeth of inner row of premaxilla pentacuspid; teeth compressed distally; and males with bony hooks on pelvic and anal fins. Bryconamericus ecai differs from other Bryconamericus species from southern South America by the following combination of characters: body depth (33.1-36.9\% SL); eye diameter (31.1-33.9\% HL); snout length (26.8-32.4\% HL); branched anal-fin rays 15-18; teeth of outer row of premaxilla regularly implanted; teeth of inner row of premaxilla tricuspid or pentacuspid; teeth compressed distally; and males with bony hooks on pelvic and anal fins.

Duas novas espécies de Bryconamericus são descritas do sul do Brasil: Bryconamericus patriciae, que habita as cabeceiras dos rios Pelotas (drenagem do rio Uruguay) e Antas (drenagem da laguna dos Patos) e Bryconamericus ecai do baixo rio Taquari. Bryconamericus patriciae difere de seus congêneres que ocorrem no sul da América do Sul pela seguinte combinação de caracteres: altura do corpo $(25,5-30,3 \% \mathrm{CP})$; comprimento da cabeça $(25,2-27,6 \% \mathrm{CP})$; comprimento da nadadeira pélvica (11,0-14,4\% CP); nadadeira anal com 14-18 raios ramificados; dentes da série externa do pré-maxilar regularmente implantados; dentes da série interna do pré-maxilar pentacuspidados; dentes comprimidos distalmente; e nadadeiras pélvicas e anal dos machos com ganchos ósseos. Bryconamericus ecai e difere de seus congêneres que ocorrem no sul da América do Sul pela seguinte combinação de caracteres: altura do corpo (33,1-36,9\% CP); diâmetro da órbita (31,1-33,9\% CC); comprimento do focinho (26,8-32,4\% CC); nadadeira anal com 14-18 raios ramificados; dentes da série interna do pré-maxilar tricuspidados ou pentacuspidados; dentes comprimidos distalmente; e nadadeiras pélvicas e anal dos machos com ganchos ósseos.

Key words: Ostariophysi, rio Uruguay, laguna dos Patos, Neotropical, systematics, taxonomy.

\section{Introduction}

Bryconamericus Eigenmann (in Eigenmann, McAtee \& Ward, 1907) is a speciose characid genus, with 51 species currently considered valid (Lima et al., 2003) inhabiting a variety of freshwater ecosystems at lower altitudes across a broad extension of South and Central America in both sides of the Andean cordilleras (Vari \& Siebert, 1990). In southern South America there are sixteen valid species for the genus: Bryconamericus agna Azpelicueta \& Almirón, B. eigenmanni (Evermann \& Kendall), B. exodon Eigenmann, B. iheringii (Boulenger), B. ikaa Casciotta, Almirón \& Azpelicueta, $B$. lambari Malabarba \& Kindel, B. menni Miquelarena,
Protogino, Filiberto \& López, B. microcephalus (Miranda Ribeiro), B. ornaticeps Bizerril \& Peres-Neto, B. pyahu Azpelicueta, Casciotta \& Almirón, B. rubropictus (Berg), $B$. stramineus Eigenmann, B. sylvicola Braga, B. tenuis Bizerril \& Araújo, B. thomasi Fowler, and B. uporas Casciota \& Azpelicueta, plus two nominal species under the synonym of B. iheringii: B. boops Eigenmann and B. pliodus (Cope).

The systematics of Bryconamericus is still unresolved and the genus lacks a phylogenetic diagnosis. The present definition was proposed by Eigenmann (1927), who included in Bryconamericus characid species that posses the following combination of characters: two rows of teeth on the premaxilla with four teeth in the inner series, a low number of teeth along

Pontifícia Universidade Católica do Rio Grande do Sul, Museu de Ciências e Tecnologia, Laboratório de Ictiologia, Av. Ipiranga, 6681, 90619-900 Porto Alegre, RS, Brazil. e-mail: pezzi@pucrs.br 


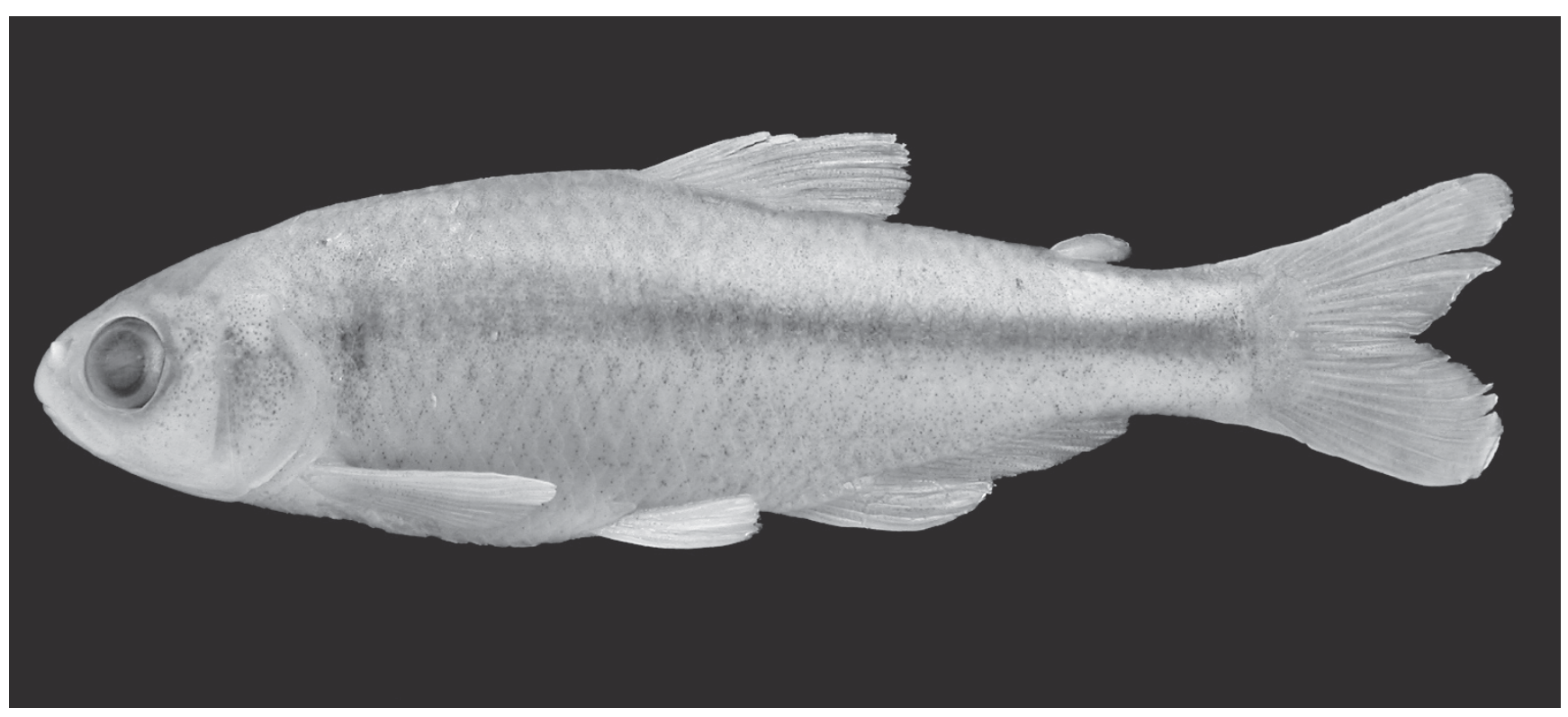

Fig. 1. Bryconamericus patriciae, holotype, MCP 19615 (47.6 mm SL, male), lateral view.

the anterior margin of the maxilla, lack of scales on the caudal fin, a large third infraorbital contacting the preopercle along its posterior and ventral margins, setiform gillrakers, a complete laterosensory canal system on the body, and the absence of a glandular pouch on the caudal fin in males. None of the listed characters is unique to the genus and most of them are actually plesiomorphic within Characidae.

This paper aims to describe two new species of Bryconamericus from southern Brazil.

\section{Material and Methods}

Counts and measurements were taken following Fink \& Weitzman (1974), except in the anal-fin base length, taken from the base of the first ray to base of the last ray of the anal fin. Counts of vertebrae including the four vertebrae of the Weberian apparatus, supraneurals, and procurrent caudal fin rays were taken from cleared and stained specimens. In the description, number enclosed by brackets after the counts are data of holotype. Data on counts and measurements for Bryconamericus agna, B. eigenmanni, B. exodon, B. ikaa, B. menni, B. pyahu, B. rubropictus, B. sylvicola, and B. thomasi were taken in the literature, while data of other species cited here were taken by the author (see comparative material). The following abbreviations are used: MACN, Museo Argentino de Ciencias Naturales "Bernardino Rivadavia", Argentina; MCP, Museu de Ciências e Tecnologia, Pontifícia Universidade Católica do Rio Grande do Sul, Porto Alegre; MLP, Museo de La Plata, Argentina; MNRJ, Museu Nacional, Rio de Janeiro and MZUSP, Museu de Zoologia da Universidade de São Paulo, São Paulo. Other abbreviations are: SL, standard length; HL, head length; and c\&s, cleared and stained for cartilage and bone according to the procedure described by Taylor \& Van Dyke (1985).

\section{Bryconamericus patriciae, new species} Fig. 1

Holotype: MCP 19615 (47.6 mm SL, male) creek tributary of rio Pelotas, on road from Silveira to Rondinha (rio Uruguay drainage), Bom Jesus, Rio Grande do Sul, Brazil, 14 January 1989, C. A. S. Lucena, E. H. L. Pereira \& P. V. Azevedo.

Paratypes: Brazil: Rio Grande do Sul: Vacaria: MCP 14376, (936, 7c\&s, 15.1-61.5 mm SL), MZUSP 84302 (20, 38.5-53.5 mm SL), MNRJ 26438 (20, 37.4-56.1 mm SL) collected with the holotype; MCP 11632 (19), arroio São Paulino, on road from Vacaria to Bom Jesus (tributary of rio Quebra-Dentes, laguna dos Patos drainage) (approx. 28³3'S 5048’W), 2 May 1985, C. A. S. de Lucena, L. R. Malabarba \& R. E. Reis. Bom Jesus: MCP 11637 (3), rio Manoel Leão near São José dos Ausentes (tributary of rio Pelotas, rio Uruguay drainage) (approx. 28 48'S 5003'W), 2 May 1985, C. A. S. Lucena, L. R. Malabarba, \& R. E. Reis.

Diagnosis. Bryconamericus patriciae differs from other Bryconamericus species, from southern South America, by the combination of body depth $(25.5-30.3 \%$ of SL, mean 28.0 versus 31.2-39.3\%, mean 34.6 in B. iheringii; $33.7-36.4 \%$ of SL, mean 34.8 in B. ikaa; and 30.5-36.9\%, mean 34.4 in $B$. ecai); head length (25.2-27.6\% of SL, mean 26.3 versus 22.5$25.3 \%$, mean 23.6 in B. lambari); pelvic fin length (11.0-14.4\% of SL, mean 12.5 versus 14.2-18.0\%, mean 15.5 (female), 16.3$21.3 \%$, mean 18.3 (male) in B. rubropictus); branched anal-fin rays (14-18 versus 19-22 in B. agna; and 22-25 in B. sylvicola); teeth of outer row of premaxilla regularly implanted (versus irregularly implanted in B. stramineus and B. exodon); teeth of inner row of premaxilla pentacuspid (versus heptacuspid in B. uporas); teeth compressed distally (versus teeth massive 
Table 1. Morphometric data for Bryconamericus patriciae and B. ecai ( $\mathrm{n}=$ number of specimens measured).

\begin{tabular}{lcccccccccc}
\hline & \multicolumn{4}{c}{ B.patriciae } & \multicolumn{5}{c}{ B.ecai } \\
\hline Character & Holotype & $\mathrm{n}$ & $\min$ & $\max$ & $\operatorname{mean}$ & Holotype & $\mathrm{n}$ & $\min$ & $\max$ & $\operatorname{mean}$ \\
Standard length (mm) & 47.6 & 26 & 41.0 & 61.5 & 49.2 & 60.6 & 14 & 50.4 & 75.1 & 58.1 \\
Percents of standard length & & & & & & & & & & \\
Predorsal distance & 54.4 & 26 & 51.7 & 55.7 & 54.0 & 53.3 & 14 & 53.2 & 55.8 & 54.3 \\
Preventral distance & 49.4 & 26 & 45.3 & 52.7 & 48.7 & 48.7 & 14 & 46.9 & 51.0 & 48.8 \\
Prepectoral distance & 26.6 & 26 & 25.0 & 28.5 & 26.5 & 24.5 & 14 & 22.4 & 26.0 & 24.2 \\
Preanal distance & 64.1 & 26 & 60.0 & 67.2 & 64.0 & 65.1 & 14 & 63.9 & 68.6 & 66.3 \\
Body depth & 29.5 & 26 & 25.5 & 30.3 & 28.0 & 35.9 & 14 & 33.1 & 36.9 & 34.9 \\
Caudal peduncle depth & 11.6 & 26 & 9.7 & 12.1 & 10.9 & 12.6 & 14 & 10.7 & 13.4 & 11.9 \\
Caudal peduncle length & 13.9 & 26 & 11.8 & 16.9 & 15.0 & 11.7 & 14 & 11.4 & 13.1 & 12.3 \\
Anal fin base length & 27.0 & 26 & 21.4 & 27.0 & 23.8 & 27.6 & 14 & 21.8 & 28.8 & 24.9 \\
Dorsal fin length & 22.8 & 26 & 19.4 & 22.8 & 21.6 & 23.9 & 13 & 20.9 & 25.5 & 23.0 \\
Ventral fin length & 14.0 & 26 & 11.0 & 14.4 & 12.5 & 17.6 & 14 & 15.3 & 19.7 & 16.5 \\
Pectoral fin length & 19.9 & 26 & 17.5 & 20.8 & 19.2 & 21.2 & 14 & 18.7 & 21.3 & 20.1 \\
Head length & 25.7 & 26 & 24.3 & 27.6 & 26.3 & 23.5 & 14 & 22.6 & 24.7 & 23.3 \\
Percents of head length & & & & & & & & & \\
Snout length & 26.7 & 26 & 23.7 & 30.4 & 27.1 & 29.6 & 14 & 26.8 & 32.4 & 29.6 \\
Maxillary length & 29.6 & 26 & 26.3 & 29.9 & 28.5 & 25.0 & 14 & 24.3 & 27.5 & 25.6 \\
Eye diameter & 32.6 & 26 & 27.0 & 32.8 & 30.4 & 32.2 & 14 & 31.1 & 33.9 & 32.3 \\
Interorbital width & 31.1 & 26 & 27.3 & 31.1 & 29.3 & 32.0 & 14 & 29.7 & 34.6 & 32.2 \\
\hline
\end{tabular}

in B. microcephalus, B. ornaticeps, and B. tenuis); males with bony hooks on pelvic and anal fins (males without bony hooks on pelvic and anal fins in B. menni and B. pyahu).

Description. Morphometric data summarized in Table 1. Body laterally compressed. Greatest body depth at origin of dorsal fin. Dorsal profile of body slightly convex from tip of supraoccipital to dorsal fin origin, nearly straight from posterior dorsal-fin base to adipose fin, and gently concave from adipose-fin base to caudal-fin origin. Ventral body profile slightly convex from isthmus to anal-fin origin, straight along anal-fin base, and gently concave from posterior of anal-fin base to caudal-fin origin.

Mouth sub-terminal, lower jaw shorter than upper jaw. Snout profile rounded from margin of upper lip to vertical through anterior nostrils, slightly convex from that point to supraoccipital. Ventral profile of head gently convex. Premaxilla with two series of teeth. Four teeth in inner row with three to five cusps, central cusp greater than others; 3 or 4 tricuspid teeth in outer row; teeth of inner row distinctly larger than teeth of outer row. Dentary with 9 to 12 teeth. Anterior six dentary teeth largest, with 3 to 5 cusps; posterior 3 to 6 teeth progressively smaller, tricuspid or conical. Maxilla with 4 to 6 , usually tricuspid teeth.

Dorsal-fin rays ii,8. First unbranched dorsal-fin ray about half length of second ray. Posterior border of dorsal fin straight; tip not reaching adipose fin when fin depressed. Dorsal-fin origin situated slightly posterior to middle of body. Adiposefin origin located at vertical through insertion of last anal-fin ray. Anal-fin rays iii-iv,14-18 (iii,17). Anal fin origin at vertical through insertion of last dorsal-fin ray. Distal border of anal fin straight or slightly concave. Anal-fin rays in males with few and tiny bony hooks, from last unbranched ray to 8th branched ray, one pair of hooks per segment and up to 10 pairs per ray, present in posterolateral surface of ray. Female without hooks on anal fin. Pectoral-fin rays i, 10-12 (i,10), distal margin slightly rounded, not reaching pelvic-fin origin. Pelvic-fin rays i,6-7 $(i, 6)$, distal margin rounded, not reaching anal-fin origin. Pelvicfin origin slightly anterior to vertical through dorsal-fin origin. Pelvic fin with few and tiny bony hooks in males, more elongate that anal bony hooks, in ventromedial surface of each ray, one hook per segment, absent on unbranched ray. Females without hooks on pelvic fin. Caudal fin forked, margin of lobes rounded, equal in size. Principal caudal-fin rays 19; 13-16 procurrent rays dorsally and 10-14 ventrally.

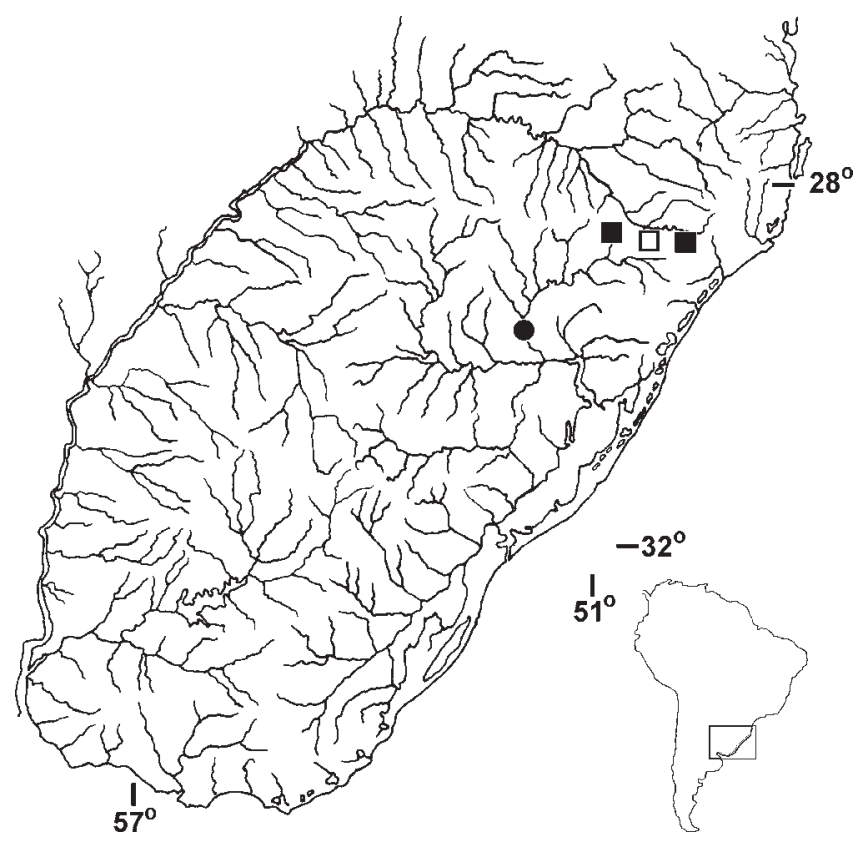

Fig. 2. Distribution of the new species of Bryconamericus $B$. patriciae (squares, open square is type-locality) and $B$. ecai (circle). 


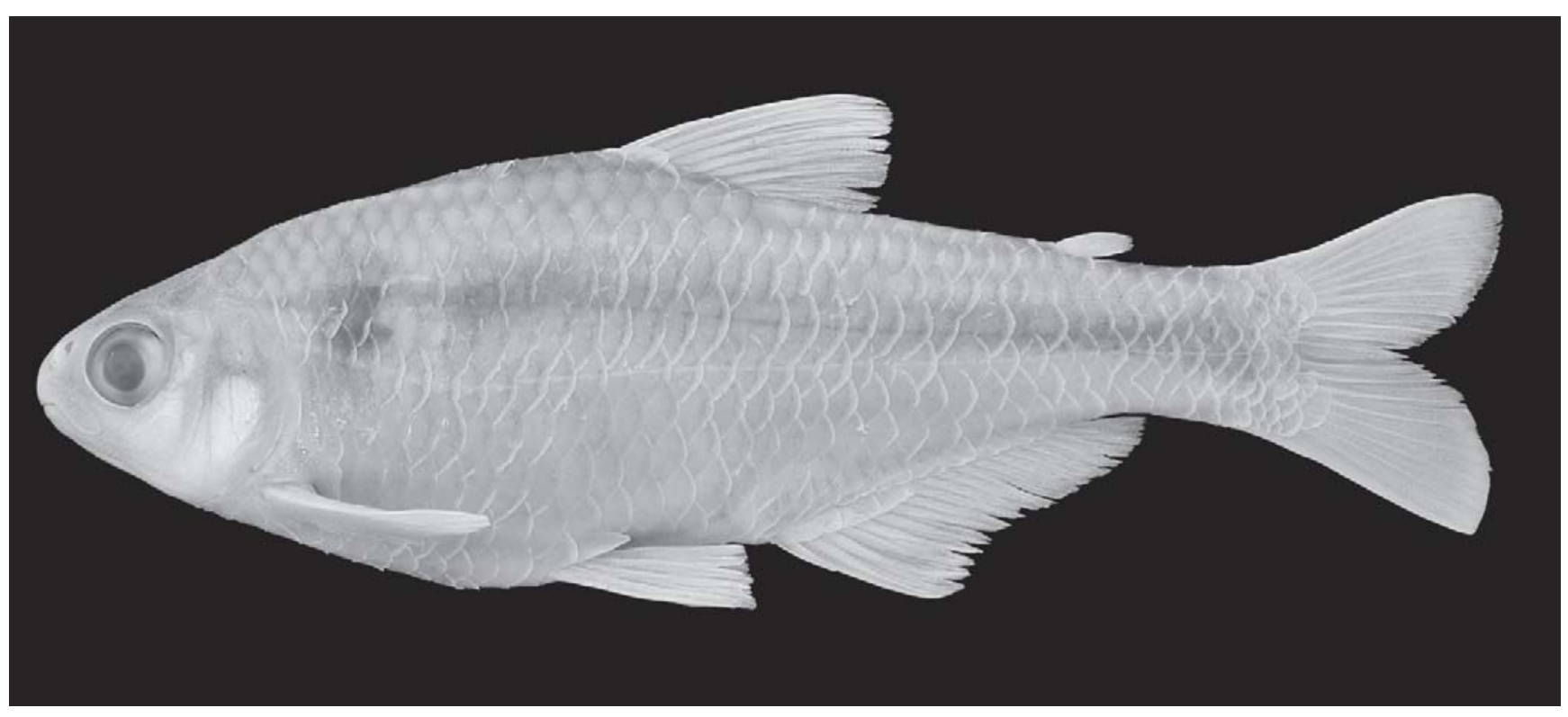

Fig. 3. Bryconamericus ecai, holotype, MCP 19608 (60,6 mm SL, male), lateral view.

Scales cycloid. Caudal fin not scaled. Single row of 4-9 (6) scales covering base of anteriormost anal-fin rays. Lateral line complete, 37-40 (38) perforated scales; 5-6 (5) scales in transverse series from dorsal-fin origin to lateral line; 4-5 (5) scales between lateral line and anal-fin origin. Predorsal scales 13-15 (15), sometimes in irregular series. Scales around caudal peduncle 14. Vertebrae: precaudal 16-17, caudal 20- 21. Supraneurals 5-6 (in seven c\&s specimens).

Color in alcohol. Ground color tan. Dorsal portions of head and body region above midlateral stripe more pigmented. Dark midlateral stripe present, more conspicuous posterior to vertical through dorsal-fin origin, not reaching upper and lower borders of caudal peduncle and not extending on base of caudal fin rays. Humeral spot faint, vertically elongate, centered on third or fourth scales of pored lateral line, and extended two series above and one below it. Pectoral, ventral, and caudal fins hyaline. Dorsal and anal fins slightly covered by dark chromatophores.

Distribution. Bryconamericus patriciae is know from the headwaters of rio Pelotas (rio Uruguay drainage) and rio das Antas (laguna dos Patos drainage) (Fig. 2).

Etymology. The specific name patriciae is given in honor to my wife Patrícia L. Gonçalves.

Habitat. Bryconamericus patriciae has been collected in rivers and creeks with clear water and light to strong water current. The bottom was formed by rocks, stones, and in some points gravel and sand. The fishes are usually found in pools below the rapids. The water temperature can drop to $7^{\circ} \mathrm{C}$ during the winter.

\section{Bryconamericus ecai, new species}

Fig. 3

Holotype: MCP 19608 (60.6 mm SL, male) creek in Linha Brasil, parallel to the road from Vila Deodoro to Venâncio Aires (tributary to arroio Castelhano, rio Taquari, laguna dos Patos drainage) (approx. 29 $33^{\prime} \mathrm{S} 52^{\circ} 17^{\prime} \mathrm{W}$ ), Venâncio Aires, Rio Grande do Sul, Brazil, 14 October 1994, Z. M. S. Lucena, C. A. S. Lucena \& J. F. Pezzi da Silva.

Paratypes: MCP 17494, (75, 7 c\&s, 13.6-75.1 mm SL), collected with the holotype.

Diagnosis. Bryconamericus ecai differs from other Bryconamericus species by the combination of body depth (33.1$36.9 \%$ of SL, mean 34.9 , versus up to $31.0 \%$ in B. lambari; $B$. patriciae; B. stramineus; and B. exodon) eye diameter (31.1$33.9 \%$ of HL, mean 32.3, versus 35.4-42.8\%, mean 39.0 in $B$. iheringii); snout length (26.8-32.4\% of HL, mean 29.6 versus 20.1-24.6\%, mean 22.2 in B. rubropictus); branched anal-fin rays (15-18 versus $18-20$ in B. ikaa; $19-22$ in B. agna; and 2225 in B. sylvicola); and teeth of inner row of premaxilla tricuspid or pentacuspid (versus heptacuspid in B. uporas); teeth compressed distally (versus teeth massive in B. microcephalus, B. ornaticeps, and B. tenuis); males with bony hooks on pelvic and anal fins (males without bony hooks on pelvic and anal fins in B. menni and B. pyahu).

Description. Morphometric data summarized in Table 1. Body laterally compressed. Greatest body depth at dorsal fin origin. Dorsal body profile slightly convex from tip of supraoccipital to dorsal-fin origin, nearly straight from posterior dorsal-fin base to adipose fin, and gently concave from adipose fin to caudal-fin origin. Ventral body profile convex from isthmus to 
anal-fin origin, straight along anal-fin base, and gently concave from posterior anal-fin base to caudal fin.

Mouth sub-terminal, lower jaw shorter than upper jaw. Snout profile rounded from margin of upper lip to vertical through anterior nostrils, nearly straight from that point to supraoccipital. Ventral profile of head gently convex. Premaxilla with two series of teeth with three to five cusps, central cusp largest, teeth with same size in both series. Inner row with four teeth, 3 to 5 in outer row. Dentary with 8 to 10 teeth. Anterior 4 to 5 dentary teeth largest, with 3 to 5 cusps, with 3 to 5 posterior teeth becoming progressively smaller, tricuspid or conical. Maxilla with 3 to 4 teeth, with 3 to 5 cusps, approximately equal in size.

Dorsal-fin rays ii,8. First unbranched dorsal-fin ray about half length of second unbranched ray. Dorsal fin posterior border straight; it tip not reaching adipose fin when depressed. Dorsal-fin origin approximately at mid-length of body. Adipose-fin origin located slightly anterior to vertical through insertion of last anal-fin ray. Anal-fin rays iii-iv,15-18 (iii,18). Anal fin origin slightly anterior to vertical through insertion of last dorsal-fin ray. Distal border of anal fin slightly concave. Last unbranched to 7 th branched anal-fin rays with few, tiny bony hooks, one pair per segment. Up to 16 hook pairs per ray, usually 10-13. Hooks present in posterolateral surface of ray. Females without hooks on anal fin. Pectoral-fin rays i, 1012 (i, 11), distal margin slightly rounded, not reaching pelvicfin origin. Pelvic-fin rays i, 6-7 (i, 7), distal margin straight, not reaching anal fin origin. Pelvic-fin origin slightly anterior of vertical through dorsal-fin origin. Male pelvic fin with thin bony hooks, more elongate than anal bony hooks, present in ventromedial surface of each ray, with one hook per segment, absent on unbranched ray. Females without hooks on pelvic fin. Caudal fin forked, lobes rounded, equal in size, not scaled. Principal caudal-fin rays 19; 11-12 procurrent rays dorsally and $10-12$ ventrally.

Scale cycloid. Anal fin with a single row of 7-10 (8) scales covering base of anteriormost rays. Lateral line complete, 3638 (37) scales; 5-6 (5) scales in transverse series from dorsalfin origin to lateral line; 4 scales between lateral line and analfin origin. Predorsal scales 12-14 (13) sometimes in irregular series. Scales around caudal peduncle 14. Vertebrae: precaudal 16-17; caudal 18-19. Supraneurals 4-6 (in six c\&s specimens).

Color in alcohol. Ground color tan. Dorsal portions of head and body region above midlateral stripe more pigmented. Dark midlateral stripe, more conspicuous posterior to vertical through distal border of pectoral fin, expanded into faint, small horizontally elongate spot on caudal peduncle, not reaching upper and lower margins of caudal peduncle and extending on base of caudal fin rays. Two humeral spots, first, vertically elongate, centered on third or fourth scales of pored lateral line and extended two series above; second spot more diffuse, without clearly marked limits. Pectoral and pelvic fins hyaline. Dorsal, anal, and caudal fin with scattered dark chromatophores

Etymology. From the Tupi-Guarani eçai, meaning small eye, in allusion to the smaller eye diameter in comparison to other Bryconamericus species.

Distribution. So far known from the type-locality a creek tributary of the lower portion of rio Taquari (laguna dos Patos drainage), Rio Grande do Sul, Brazil.

Habitat. Bryconamericus ecai was found in a creek with clear to turbid water, light to moderate water current and bottom with stones and sand.

\section{Discussion}

The monophyly of Bryconamericus has been discussed by several authors, since Eigenmann (1927:358). Most recently Vari \& Siebert (1990) admitted to have little confidence that Bryconamericus in its broad sense represents a natural (monophyletic) component of Characidae, a statement also supported by Malabarba \& Malabarba (1994). Roman-Valencia (2000) considered Bryconamericus as valid and a natural group of Characidae, in a broader concept than Eigenmann (1927), including Knodus and Eretmobrycon as junior synonyms. He also considered Bryconamericus related to Hemibrycon, but did not present a phylogenetic evidence to support his hypothesis. Lima et al. (2003), however, considered Knodus as a valid genus distinct from Bryconamericus. The relationships between Bryconamericus, Knodus, and Eretmobrycon are uncertain. Bryconamericus is most probably a polyphyletic genus, with many groups of species. Eigenmann (1927: 358) commented "There are three or four recognizable groups in the genus Bryconamericus and these may have been independently derived from various species of Astyanax or Hemibrycon". Silva (1998) recognized three groups of Bryconamericus species from Southern South America based manly in the position and form of the maxillary teeth: the B. exodon group, including B. stramineus, with the outer row of premaxillary teeth irregularly implanted, mouth terminal, and teeth like Astyanax - these species occur in the rio Paraná-Paraguay system (B. exodon and B. stramineus), rio São Francisco, and rio Uruguay system (B. stramineus) but not sympatric with $B$. patriciae. The $B$. microcephalus group, including $B$. ornaticeps and B. tenuis, with the outer row of premaxillary teeth regularly implanted, mouth inferior, and teeth massive (similar to tooth found in Creagrutus), these species occur in Atlantic coastal rivers between Paraná and Rio de Janeiro state. And the $B$. iheringii group, including all other species from southern South America, with the outer row of premaxillary teeth regularly implanted, mouth sub-terminal, and teeth compressed distally. The two new species described here belong to the $B$. iheringii group.

Comparative material: Bryconamericus iheringii: $\mathrm{BMNH}$ 1886.3.15.30, 1 (lectotype), São Lourenço do Sul, Rio Grande do Sul, Brazil; BMNH 1886.3.15.34, 11 (paralectotypes) collected with lectotype; MCP 19293, 44, lago Guaíba near the mouth of arroio do Ribeiro, Barra do Ribeiro, Rio Grande 
do Sul, Brazil. Bryconamericus lambari: MCP 15448 (holotype) small creek following into arroio Feitoria, under the bridge of avenida Ipiranga, Dois Irmãos, Rio Grande do Sul, Brazil; MCP 15449, 14 (paratypes) collected with holotype. Bryconamericus microcephalus: MNRJ 2576, 1 (Lectotype), rio Betari (tributary of rio Ribeira do Iguape), Iporanga, São Paulo, Brazil; MNRJ 12311, 1 (Paralectotype), collected with Lectotype; MCP 19707, 24, rio Betari, in the bairro da Serra, ca $13 \mathrm{~km} \mathrm{WNW}$ to Iporanga (tributary of rio Ribeira do Iguape), Iporanga, São paulo, Brazil. Bryconamericus tenuis: MNRJ 12231, 26 (paratypes), rio São João, Silva Jardim, Rio de Janeiro, Brazil. Bryconamericus ornaticeps: MNRJ 12313, 19 (paratypes), rio Macacu, Cachoeira de Macacu, Rio de Janeiro, Brazil. Bryconamericus stramineus: MCP 12049, 22, rio Canoas, at Passo do Canoas, on road from Tupitinga to Celso Ramos (273' $\left.11^{\prime \prime S} 51^{\circ} 24^{\prime} 9^{\prime \prime} \mathrm{W}\right)$, Tupitinga, Santa Catarina. Bryconamericus uporas: MCP 19664, 78, arroio Canoin, on road from Pirapó to São Nicolau, São Nicolau, Rio Grande do Sul, Brazil; MCP 19611, 1, same locality.

\section{Acknowledgments}

I am grateful to Luiz R. Malabarba and two anonymous reviewers for their comments and suggestions on the manuscript. I also thank Gustavo Chiaramonte (MACN), Maria de las Mercedes Azpelicueta and Amalia Miquelarena (MLP) for their assistance and hospitality.

\section{Literature cited}

Eigenmann, C. H. 1927. The American Characidae. Memoirs of the Museum of Comparative Zoology, 63(4): 358-395.

Eigenmann, C. H., W. L. Mcatee \& D. P. Ward. 1907. On further collection of fishes from Paraguay. Annals of Carnegie Museum, 4(2): 139-140.

Fink, W. L. \& S. H. Weitzman. 1974. The so-called cheirodontin fishes of Central America with descriptions of two new species (Pisces: Characidae). Smithsonian Contributions to Zoology, 172:1-46.
Lima, F. C. T., L. R. Malabarba, P. A. Buckup, J. F. P. Silva, R. P. Vari, A. Harold, R. Benine, O. T. Oyakawa, C. S. Pavanelli, N. A. Menezes, C. A. S. Lucena, M. C. S. L. Malabarba, Z. M. S. Lucena, R. E. Reis, F. Langeani, L. Casatti, V. A. Bertaco, C. Moreira \& P. H. F. Lucinda. 2003. Genera Incertae Sedis in Characidae. Pp. 106-169 In: Reis R. E., S. O. Kullander \& C. J. Ferraris, Jr. (Eds.), Check List of the Freshwater Fishes of South and Central America. Porto Alegre, Edipucrs, 729p.

Malabarba, M. C. S. L. \& L. R. Malabarba. 1994. Hypobrycon maromba, a new species and genus of characiform fish from the upper rio Uruguay, Brazil (Ostariophysi: Characidae). Ichthyological Exploration of Freshwaters, 5(1): 19-24.

Roman-Valencia, C. 2000. Tres nuevas especies de Bryconamericus (Ostariophysi: Characidae) de Colombia y diagnóstico del género. Revista de Biología Tropical, 48 (2/3): 449-464.

Silva, J. F. P. 1998. Revisão taxônomica das espécies de Bryconamericus (Eigenmann, 1907) do sul e sudeste do Brasil (Ostariophysi, Characidae). Unpublished Master Dissertation, Pontifícia Universidade Católica do Rio Grande do Sul, Porto Alegre. 107 p.

Taylor W. R. \& G. C. Van Dyke 1985. Revised procedures for staining and cleaning small fishes and other vertebrates for bone and cartilage study. Cybium, 9: 107-19.

Vari, R. P. \& D. J. Siebert 1990. A new, unusually sexually dimorphic species of Bryconamericus (Pisces: Ostariophysi: Characidae) from the Peruvian Amazon. Proceedings of the Biological Society of Washington. 103(3): 516-524.
Received April 2004 Accepted May 2004 